vocational guidance. It is true we have not yet reached the stage of development where we can prepare a complete program of professional training such as that which I outlined above. Nevertheless we can already make a start toward it, and if we keep in mind the fundamental principles of professional education, we shall find that the curriculum we shall eventually evolve will be sound and on a truly professional plane.

\title{
A TRAINING PROGRAM FOR VOCATIONAL COUNSELORS
}

\author{
GEORGE E. MYERS \\ Professor of Vocational Education and Guidance, University of Michigan
}

It is quite obvious that two things are fundamental in planning a program of training for any kind of position or occupation: (1) the nature of the work to be done; and (2) the sort of people who are called upon to do it, that is, the other qualifications which are desired in these people besides special training for the work. This is not the place to enter into an extensive discussion of either of these topics in relation to counseling. It is taken for granted that you have a fairly definite idea of the work which a vocational counselor should be expected to do and that this will serve as a background for the discussion.

It is well to remind ourselves, however, that among the qualifications, aside from special training, which those who select counselors often emphasize are: (1) a personality which attracts and gets on well with adolescents; (2) sufficient maturity to command the respect of pupils and fellow teachers; (3) at least as good a general education as is possessed by the average high school teacher, usually represented by graduation from a college of good standing; (4) successful experience as a teacher; and (5) preferably, some business or industrial experience.

We shall, then, do well to recognize at the outset that, on account of the nature of the work to be done and especially on account of the maturity, the general education, and the experience of those who are called upon to do it, the special training of counselors is largely a graduate undertaking. This does not mean that we are not interested in the undergraduate work of those who are to be counselors. We should be intensely interested in this, but chiefly to the end that it shall be well-rounded and provide good preparation for teaching. Personally, I would like to see hygiene, general biology, heredity, economics, and sociology stressed in the undergraduate work of all students. And for those who are to teach, much attention, of course, is necessary to psychology and education. A single course in vocational guidance, which opens up the problem and shows the nature of the work to be done, also may well be included in the undergraduate preparation of all high school teachers. This would serve to acquaint this body of teachers generally with the guidance movement and make them sympathetic with the counselor's work. It would also aid in discovering individuals who should later make special preparation for counseling and other guidance work. But those who, as young undergraduates, become interested in counseling should understand that their best approach to this work is through teaching, fol- 
lowed or accompanied by graduate study. Also, they may well try themselves out in counseling before beginning special training for this work, along with their teaching, by assisting voluntarily the regularly appointed counselors.

In presenting the following list of courses which are desirable for one to take who is to become a counselor, it has seemed wise to arrange them by departments without reference to whether they are graduate or undergraduate courses. As actually offered, many of them are open to both seniors and graduates. The student who has taken a large number of these courses as an undergraduate will have less to take as a graduate. It should be understood, however, that all but one of the courses in the list headed vocational guidance is graduate work, and this course should be so conducted as to carry graduate credit for those who have not taken it as undergraduates. Also, there is enough work proposed to entitle one who completes it to the master's degree.

Sociology. It is proposed that a course in the principles of sociology be followed by other courses dealing with urban sociology, community problems, the family, and the principles of social case work. As these courses are given in the University of Michigan they comprise fourteen semester hours of work. A counselor who is to prove effective in helping boys and girls interpret occupational information and try-out or exploratory experiences in terms of their individual characteristics and limitations, must take into account the family and community environment from which they come and must know how to study that environment effectively. Since there is a close similarity between social case work and vocational counseling, he should be able to take advantage of the principles and methods which have been developed through years of experience and study in this related field.

Econonics. In addition to knowing the fundamentals in this field the counselor should take courses dealing with labor problems, particularly with the organization, policies, and activities of labor unions, labor legislation affecting employment of minors, workmen's compensation laws, etc.; industrial and business organization, with special attention to organization charts, functions of different departments, relations between department:, etc.; and personnel management,-a total of twelve to fifteen semester hours including the elementary courses. Such courses are essential to a proper understanding by the counselor of the occupational information which he presents to his pupils, and to the giving of sound advice in placement matters. Such courses are valuable also in calling the counselor's attention to important ramifications of the vocational guidance problem in the management of business and industry.

Psychology. A course in general psychology should be followed by one or more courses in educational psychology with emphasis upon the learning process, habit formation, etc.; the psychology of individual differences; 'social psychology ; group and individual intelligence tests; statistical method as applied to mental and social measurements; vocational psychology with special reference to selection, assignment, transfer and promotion of workers; and abnormal psychology or the psychology of exceptional children. These courses call for eighteen to twenty semester hours of work. In every aspect of the vocational counselor's work one or more of these phases of psychology has important applications. Educational psychology has its chief significance in the 
teaching of occupational information. The psychology of individual differences and the results of intelligence tests have important applications in advising concerning choice of try-out experiences, in helping pupils interpret occupational information and experiences in relation to their characteristics and limitations, in advising concerning special training and placement, and in follow-up work with those who fail and with those who succeed. Some knowledge of statistical method is essential to the proper interpretation and use of the results of intelligence and other tests. Vocational psychology probably has its chief significance in placement and follow-up problems of the counselor, though the whole question of special aptitude tests is involved also. The psychology of exceptional children is valuable as an aid in discovering and dealing with mental, temperamental, and emotional abnormalities that every counselor will encounter in various aspects of his work.

Education. It is proposed that the work in this field include a course in each of the following: philosophy of education, school administration, principles of teaching in secondary schools, the high school curriculum, and introduction to vocational education, - a total of fourteen or more semester hours, in addition to such directed teaching, or practice teaching, as may be included in preparation for teaching.

It is clear that vocational counseling is essentially an educational function carried on in a school system, and specifically in the junior and senior high schools of that system. It is important, therefore, that the one who performs this function shall know the more fundamental principles which underlie education, shall be acquainted with its organization and administration, and shall be familiar with the objectives, cur- ricula, and methods of secondary schools. The course in vocational education should acquaint the prospective counselor with training opportunities - full-time, part-time, evening, and correspondence - for all kinds of occupations, whether these opportunities are provided by public or private educational institutions or in employment itself.

Vocational Guidance. At least the following courses should be included: introduction to vocational guidance, a subject-matter course in occupational information, a course in the technique of individual counseling, observation and practice work in counseling, and a special problems or seminar course. This calls for twelve semester hours of work, the problems course calling for four hours and each of the others, two hours.

The first of these courses should give the student an overview of vocational guidance, an appreciation of its place in a system of public education, a general idea of what constitutes a comprehensive program of guidance, and an understanding of the counselor's place in such a program. The second should acquaint him with information concerning a wide range of occupations, and with the procedure in gathering and using such information effectively. It should involve carefully supervised first-hand investigation of opportunities and requirements in a limited number of occupations. The course in the technique of individual counseling should aim to aid the counselor in bringing to a focus in his interview with a pupil occupational information and the psychological, social, and educational data available. Analysis of data and methods of procedure in typical cases, or case studies, would claim considerable attention. Observation and practice work are, of course, fundamental in training for 
such an occupation as that of vocational counselor, though as yet difficult to provide adequately. The purpose of the special problems course is to introduce the counselor to research methods in his field and to build up an interest in making investigations later in his work as counselor.

It should be understood that the above constitutes the minimum training desirable for a counselor. As already noted, industrial or business experience, even though limited to summer employment, will prove an additional asset of decided value. Some of those who prepare as undergraduates for high school teaching will have had enough work in economics, sociology, psychology, and education to make it possible for them to complete the above minimum in one year of graduate study. This minimum should be considered necessary and adequate for the master's degree.

Those who wish to go further in preparation for vocational counseling should be expected to take considerable additional work of research character in vocational guid- ance, and such further work in the cognate fields as special problems in individual differences, race psychology, social psychiatry, immigration, the labor movement, personnel management, etc.

At the present time all but two of the courses mentioned above are offered in the University of Michigan. The two for which provision is yet to be made, at least one of which it is expected will be offered next year, are the technique of individual counseling, and observation and practice work in counseling,--both quite important courses.

It will be noted that in this discussion only vocational counseling has been considered. No attention has been given to counseling in matters of health, morals, social activities. general education, and the like, except in so far as these may be involved in vocational counseling. This has been done deliberately because it was believed better to give the discussion as definite a focus as possible. Probably the program of training proposed above would be found fairly adequate for these other phases of counseling also.

\title{
TRAINING FOR EDUCATIONAL AND VOCATIONAL COUNSELORS FROM THE STANDPOINT OF THE FIELD WORKER
}

\author{
AnNa B. Pratt \\ Director, White-Williams Foundation, Philadelphia
}

The majority of educators today are recognizing the fact that unless one has had some experience in doing a thing, the repetition of words about how to do it is futile. The classic illustration is driving a car,you may study the process of starting, going, and stopping, and you may pass a creditable examination on paper, but unless you have done the things about which you write, over and over, until they become a habit, no one would engage you for a chauffeur. Universities are recognizing this in their scientific departments. Who would think today of learning chemistry or physics without a laboratory? More recently psychology has demanded the same kind of training. No one would now accept the results of psychometric tests unless the psychologist had 